\title{
중증열성혈소판감소증후군
}

서울대학교 의과대학 내과학교실

김계형 · 오명돈

\section{Severe Fever with Thrombocytopenia Syndrome}

\author{
Kye-Hyung Kim and Myoung-Don Oh \\ Department of Internal Medicine, Seoul National University College of Medicine, Seoul, Korea
}

Severe fever with thrombocytopenia syndrome (SFTS) is firstly reported in China in 2011. It is an emerging infectious disease in China, Japan and South Korea. It is caused by novel bunyavirus, called SFTS virus. The vector of SFTS is Haemaphysalis longicornis tick and domesticated animals may serve as intermediate hosts. The clinical manifestations of SFTS are fever, vomiting, diarrhea, thrombocytopenia and leukopenia. In severe cases, multiple organ failure, disseminated intravascular coagulopathy, and central nervous systems manifestation are present. The case-fatality rate is $6-30 \%$. There is no effective antiviral therapy and supportive care is the main treatment. (Korean J Med 2014;86:271-276)

Keywords: Severe fever with thrombocytopenia syndrome; Phlebovirus; Bunyavirus

\section{서 론}

신종 감염병은 전 세계적으로 1940 년대부터 증가하고 있 다. 신종 감염병 가운데 매개체가 전파하는 감염병은 $22.8 \%$ 를 차지할 정도로 그 비중이 높다. 매개체는 강수량이나 기 온에 민감하여 1990년대부터 심화된 기후변화로 인해 매개 체감염병에 의한 신종 감염병이 증가하고 있다[1].

중증열성혈소판감소증후군(severe fever with thrombocytopenia syndrome, SFTS)은 2011년에 중국에서 보고된 새로 운 매개체감염병이다[2]. SFTS의 주요한 증상과 징후는 발 열, 복통, 구역, 구토, 혈소판 감소증 및 백혈구 감소증이다. 중증 환자는 다발성 장기부전이 발생하며 치사율은 $6-30 \%$
이다[2-5]. 이 질환은 중국에 이어 일본에서도 보고되었고[6] 2013년에는 국내에서도 보고되었다[7]. 여기서는 SFTS의 원 인병원체, 역학, 임상양상, 진단 등에 대해 기술하고자 한다.

본 론

\section{원인병원체}

SFTS의 원인병원체는 중증열성혈소판감소증후군 바이러 스(SFTS virus, SFTSV)이며 이 바이러스는 버냐바이러스 과(Bunyaviridae family)에 속한다[2]. 버냐바이러스과는 세 개의 분절을 포함한 음성가닥(negative-strand) RNA 바이러스 인데, 오르토버냐바이러스(Orthobunyavirus), 한타바이러스

Correspondence to Myoung-Don Oh, M.D.

Department of Internal Medicine, Seoul National University College of Medicine, 103 Daehak-ro, Jongno-gu, Seoul 110-744, Korea Tel: +82-2-2072-2945, Fax: +82-2-762-9662, E-mail: mdohmd@snu.ac.kr 
- The Korean Journal of Medicine: Vol. 86, No. 3, 2014 -

(Hantavirus), 나이로바이러스(Nairovirus), 플레보바이러스 (Phlebovirus), 토스포바이러스(Tospovirus)를 포함하는 다섯 개의 속(genus)로 이루어져 있다[8]. 이 가운데 국내에서 유행 하는 바이러스는 한타바이러스 속(Hantavirus genus)의 한탄 바이러스(Hantaan virus)와 서울바이러스(Seoul virus)가 있다. SFTSV는 플레보바이러스 속(Phlebovirus genus)에 속하며[2], 여기에 리프트밸리열바이러스(Rift valley fever virus) 등이 있다[8].

SFTSV는 지름이 80-100 nm인 공 모양의 바이러스이다. 이 바이러스는 single-stranded negative sense RNA segment인 큰 분절(large (L) segment), 중간 분절(medium (M) segment) 그 리고 작은 분절(small (S) segment) 이렇게 3 개의 유전자를 지 니고 있다[8].

\section{역학}

2009년 6월에 중국 허난성에서 발생한 환자에서 처음으 로 바이러스가 분리되었다[2]. 중국에서 발생한 환자의 남녀 비는 여성이 $53.3 \%$ 로 남성보다 약간 더 많았으며 환자의 나 이는 중앙값이 58세로 노인층에서 주로 발생하였다. 발생 시 기는 4월부터 11월까지이며 대개 7-8월에 집중적으로 발생 하고 있다. 환자의 직업은 농업 또는 임업이 $81.4 \%$ 를 차지하 였으며 발생지역은 허난성(48.2\%), 후베이성 $(21.9 \%)$, 산둥성 (15.7\%)이 대부분을 차지하였다. 사망한 환자의 연령은 64세 (중앙값, 범위 38-94세)로 70세 이상의 고령 환자가 주로 사 망하는 것으로 나타났다[3]. 과거에 원인이 밝혀지지 않았던 집단발병 사례를 후향적으로 조사한 연구에서 중국 최초의 SFTS 사례는 2006년에 발생하였다. 이 사례는 처음에 아나 플라즈마증으로 추정하였으나 2012년에 비로소 SFTSV가 검 출되어 확진되었다[9].

일본의 SFTS는 2012년 가을에 야마구치현에 사는 50대 여성에게 발병한 사례에서 처음으로 진단되었다[6]. 이후 수 행된 후향적 연구에서 환자 11 명이 추가로 확인되었는데, 이 들 가운데 6 명은 사망한 환자였다. 사망한 환자 모두 나이가 50 세 이상이었고 서일본 지역(야마구치, 나가사키, 히로시마, 사가, 미야자키 등)에서 보고되었다. 발생 시기는 3 월부터 8월까지이며 5월에 가장 많은 환자가 발생하였다. 후향적 연 구에서 가장 이른 증례는 2005년에 발생한 환자였다[6].

우리나라의 SFTS는 강원도 춘천시에 거주하던 63세 여성 에서 처음으로 확진되었다. 이 환자는 2012년 8월에 발열,
백혈구 감소증, 혈소판 감소증이 발생하였으며 다장기부전 으로 사망하였다. 환자의 혈액에서 SFTSV가 분리되어 2013 년 5월에 보고되었다[7]. 2013년 11월말까지 질병관리본부에 신고된 의심 환자는 모두 404건이며 이 가운데 36명이 SFTS 로 확진되었고 확진 환자 가운데 17 명이 사망하였다. 발생지 역은 제주, 전남, 경북, 강원도 등으로 한반도 전역에 걸쳐서 발생하였다[10]. 환자들의 평균 연령은 69세로 고령층이 대부분을 차지하였고 농부가 $75.8 \%$ 를 차지하였다. 발생 시 기는 5 월부터 10 월까지이며 7 월에 가장 많은 환자가 발생하 였다.

\section{감염경로}

SFTS는 진드기에 물렸을 때 감염되는 것으로 알려져 있다. 매개하는 진드기는 작은소참진드기(Haemaphysalis longicornis) 이다. 꼬리소참진드기(Rhipicephalus microplus)도 SFTSV를 매개한다고 보고되었다[2,11]. 이는 유행지역의 가축과 환경 에서 채집한 진드기의 약 $4.9 \%$ 에서 SFTSV가 검출되었고 검 출된 바이러스의 핵산염기서열이 환자나 다른 포유동물 숙 주에서 확인된 것과 $95-100 \%$ 일치하였기 때문이다[2,11,12]. 중간숙주를 찾기 위한 연구에서 가축의 SFTSV 항체 양성률 은 3.1-69.5\%까지 다양하였고 바이러스혈증은 $1.7-4.2 \%$ 에서 확인되었다[13]. 또한 산둥성 지역 염소는 $83 \%$ 에서 항체 양성률을 보였다[12]. 이들 연구에서 염소, 양, 돼지, 개 등과 같은 짐승에서 항체 양전과 바이러스혈증이 확인되어 이들이 SFTSV의 중간숙주로 지목되고 있다[12,13].

우리나라에도 작은소참진드기는 널리 서식하고 있고[14,15] 2011-2012년에 채집한 작은소참진드기에서 SFTSV가 검출되 었다[16]. 환자의 혈액에는 SFTSV가 검출되며 특히 중증 환 자의 혈액에는 SFTSV 농도가 매우 높으므로 혈액을 통해 사람-사람 간 전파가 가능하다[9,17-20].

\section{발병기전}

SFTS의 주요 징후는 백혈구 감소증, 혈소판 감소증, 전신 염증반응증후군, 응고장애, 다발성장기부전증이다. SFTS 환자 들에서는 interleukin-6, interleukin-10, interferon- $\gamma$, granulocyte colony stimulating factor와 같은 사이토카인이 높고 fibrinogen, hepcidin, phospholipase A2가 상승한 것이 확인되었는데, 그 결과 전신염증반응증후군이 나타나게 된다[4,21,22].

SFTS의 가장 큰 특징인 혈소판 감소증의 발병기전 연구 
- Kye-Hyung Kim, et al. Severe fever with thrombocytopenia syndrome -

를 위해서 C57BL/6 마우스 모델이 수립되었다. 이 동물모델 에서 SFTSV RNA는 혈액, 비장, 간, 신장에서 검출되었다[23]. 비장과 골수의 조직병리학적 변화는 감염 초기인 7일째부터 나타나기 시작하여 14 일째 이후 점차 회복되었고 간과 신장 의 변화는 감염 14 일째에 가장 심했다가 28 일째에 회복되었 다. 바이러스 증식은 비장에서만 검출되었는데, 특히 SFTSV 가 검출된 위치는 비장의 적색속질에 있는 대식세포의 세포 질이었다. 또한 SFTSV가 혈소판에 부착된 것이 확인되었고 이러한 결과로 보아 SFTS 환자의 혈소판 감소증은 SFTSV가 부착된 혈소판이 비장에서 대식세포에 탐식되어 발생하는 것으로 추정된다[23].

\section{임상소견 및 검사결과}

바이러스 노출에서 증상이 나타날 때까지의 잠복기는 대 개 1-2주로 알려져 있다[9,17-20]. 국내에서 발생한 SFTS 환 자의 역학조사 결과에 따르면 진드기에 물린 시점부터 증상 이 나타나기까지 잠복기는 4-15일이었다[24].

흔한 증상은 고열, 피로감, 두통, 근육통, 복통, 구토, 설사, 기침 등 비특이적인 증상들이다[2,25]. 흔한 징후는 혈소판 감소증, 백혈구 감소증, 림프절 병증, 위장관 출혈 등이다 (Tables 1 and 2) [2,5,25]. 국내 환자들도 비슷한 임상 소견을 보였다(Table 3) [24].
SFTS의 임상병기는 발열기, 다장기부전기, 회복기로 나눌 수 있다[5]. 제1기인 발열기는 증상시작으로부터 1-7일간의 기간으로 사망 환자와 생존 환자 모두에서 혈중 바이러스양 이 $10^{5}-10^{6}$ copies $/ \mathrm{mL}$ 로 높다. 이 시기에는 혈소판 감소증, 백

Table 2. Laboratory findings of severe fever with thrombocytopenia syndrome

\begin{tabular}{lcc}
\hline \multirow{2}{*}{ Laboratory variables } & \multicolumn{2}{c}{ No. of patients with respective signs (\%) } \\
\cline { 2 - 3 } & Xu B, et al. [25] & Yu XJ, et al. [2] \\
\hline Thrombocytopenia & $234(98.3)$ & $69 / 73(95)$ \\
Leukopenia & $232(97.5)$ & $64 / 74(86)$ \\
Elevated AST & $234(98.3)$ & $53 / 64(83)$ \\
Elevated ALT & $234(98.3)$ & $59 / 63(94)$ \\
Elevated LDH & $221(92.9)$ & $49 / 51(96)$ \\
Elevated CK & $166(69.8)$ & $25 / 49(51)$ \\
Elevated CK-MB & NA & $28 / 47(60)$ \\
Elevated aPTT & NA & $56(69)$ \\
Proteinuria & NA & $40(49)$ \\
Hematuria & NA & $34(42)$ \\
Fecal occult blood & NA & $61(75)$ \\
\hline AST.
\end{tabular}

AST, aspartate aminotransferase; ALT, alanine aminotransferase; $\mathrm{LDH}$, lactate dehydrogenase; $\mathrm{CK}$, creatine kinase; CK-MB, MB fraction of creatine kinase; aPTT, activated partial prothrombin time; NA, not applicable.

Table 1. Clinical manifestations of severe fever with thrombocytopenia syndrome

\begin{tabular}{lccc}
\hline \multirow{2}{*}{ Clinical symptoms } & \multicolumn{3}{c}{ No. of patients with respective symptoms (\%) } \\
\cline { 2 - 4 } Fever & Liu W, et al. [27] & Xu B, et al. [25] & Yu XJ, et al. [2] \\
Fatigue & $311(100)$ & $232(97.5)$ & $81(100)$ \\
Myalgia & NA & $223(93.7)$ & $53(65)$ \\
Arthralgia & $257(82.6)$ & $165(69.3)$ & $32(46)$ \\
Headache & NA & $80(33.6)$ & NA \\
Nausea & $54(17.4)$ & $146(61.3)$ & $10(12)$ \\
Vomiting & $158(50.8)$ & $181(76.1)$ & $56(69)$ \\
Abdominal pain & $114(36.7)$ & $153(64.3)$ & $56(69)$ \\
Diarrhea & NA & $134(56.3)$ & $40(49)$ \\
Anorexia & $80(25.7)$ & $156(65.6)$ & $34(42)$ \\
Cough & $302(97.1)$ & $219(92.0)$ & $61(75)$ \\
Dizziness & $99(31.8)$ & $119(50.0)$ & $8(10)$ \\
LN enlargement & $60(19.3)$ & $164(68.9)$ & NA \\
\hline NA, & $132(42.4)$ & $128(53.8)$ & $23(33)$
\end{tabular}

NA, not applicable; LN, lymph node. 
Table 3. Demographic and clinical characteristics of 33 Korean patients with severe fever with thrombocytopenia syndrome [24]

\begin{tabular}{ll}
\hline Characteristics & No. $(\%)$ \\
\hline Demographic features & $18(45)$ \\
Male sex & $69(28-84)$ \\
Age (year), median (range) & $25(75.8)$ \\
Farm workers & $15(45.5)$ \\
Fatal cases & \\
Clinical manifestation & $4-15$ \\
Incubation period (days from tick bite to & \\
clinical symptoms) & $33(100)$ \\
Fever & $16(48.5)$ \\
Myalgia & $28(84.8)$ \\
Gastrointestinal symptoms & $16(48.5)$ \\
$\quad$ Vomiting & $23(69.7)$ \\
$\quad$ Diarrhea & $22(66.7)$ \\
Confusion & \\
Laboratory findings & $33(100)$ \\
Thrombocytopenia & $33(100)$ \\
Leukopenia & $33(100)$ \\
Elevated AST & $31(93.5)$ \\
Elevated ALT & $30(100)^{\mathrm{a}}$ \\
Elevated LDH & $24(92.3)^{\mathrm{b}}$ \\
\hline
\end{tabular}

AST, aspartate aminotransferase; ALT, alanine aminotransferase; LDH, lactate dehydrogenase; CK, creatine kinase; aPTT, activated partial prothrombin time.

${ }^{\mathrm{a}}$ Total number of cases was 30 .

${ }^{\mathrm{b}}$ Total number of cases was 26 .

혈구 감소증이 나타나고 아스파르테이트아미노전달효소 (aspartate aminotransferase, AST), 알라닌아미노전달효소(alanine aminotransferase, ALT), 젖산탈수소효소(lactase dehydrogenase, $\mathrm{LDH})$, 크레아틴키나아제(creatine kinase, CK), CK-MB가 상승하기 시작한다. 제 2 기인 다장기부전기는 발병 7-13일 간의 기간으로 생존 환자에서는 혈중 바이러스 농도는 감소 하나 사망환자에서는 지속적으로 바이러스 농도가 $10^{8} \mathrm{copies} / \mathrm{mL}$ 까지 증가한다. 생존 환자에서는 혈소판 수치가 회복되나 사 망자에서는 지속적으로 감소하게 된다. 발병 5-9일에는 활성 화부분트롬보플라스틴시간(activated partial thromboplastin time, aPTT)이 지연된다. 이 시기에 단백뇨와 혈뇨도 볼 수
있다. 제 3 기인 회복기는 발병 13 일 이후로 생존 환자에서는 대부분의 임상 소견이 정상으로 회복된다. 그러나 사망 환자 에서는 혈중 효소 농도가 급격히 상승하게 되고 심한 다발 성장기부전과 파종혈관내응고로 인해 사망하게 된다.

이 질환의 치사율은 초기 보고에서는 $30 \%$ 에 이르렀지만 최근 중국의 보고에서는 6-15\%로 떨어졌다[2,3,26]. 2013년 11 월 말까지 발생한 국내 환자는 36 명이며, 이 가운데 17 명 이 사망하여 치사율은 $47.2 \%$ (17/36)이었다[10].

사망과 연관된 위험인자들은 고령, 중추신경계 이상, 출혈 소견, 파종혈관내응고, 다장기부전의 임상소견이 동반된 경우, 그리고 높은 혈중 바이러스 농도, $\mathrm{AST}, \mathrm{LDH}, \mathrm{CK}, \mathrm{CK}-\mathrm{MB}$, aPTT 등이다[5,27].

병리소견은 잘 기술되어 있지 않다. 일본에서 보고된 확진 환자 1 명의 부검에서 심한 괴사성 림프절염과 림프절, 골수, 비장의 혈구탐식이 관찰되었다. 그 외 확진 환자 4 명의 골수 에서도 혈구탐식이 확인되었다[6]. 그러나 중국에서 보고된 환자 10 명의 골수세포흡인검사 결과는 정상이었고 환자 4 명 의 골수조직 검사도 정상인과 비슷한 소견이었다[28]. 이렇게 병리소견이 연구에 따라서 서로 다르므로 앞으로 더 많은 환자를 대상으로 한 연구 결과가 필요하다.

\section{진단}

SFTS 진단에 중요한 소견은 발열, 혈소판 감소증, 백혈구 감소증 그리고 진드기에 노출된 역학정보이다[2,29]. 검사실 진단은 바이러스 분리, 급성기의 바이러스 유전자 검출, 회 복기 혈청의 특이 항체가( $\mathrm{IgG})$ 가 급성기에 비해 4 배 이상 증 가한 경우 중 한 가지 이상을 만족하면 된다[2,29].

바이러스는 급성기 혈청 또는 전혈을 베로 세포(Vero cell) 또는 DH82 세포에 접종하여 분리한다[6,28]. 바이러스 유전자 검출은 바이러스의 3 개 $\mathrm{L}, \mathrm{M}, \mathrm{S}$ 분절의 특정 부위를 검출하 는 역전사중합효소연쇄반응을 이용한다. 2013년에 중국에서 개발된 실시간 역전사중합효소연쇄반응법(real-time RT-PCR) 은 민감도 $98.6 \%$, 특이도 $99 \%$ 를 가진다[30].

혈청검사는 간접면역형광항체법, 효소결합면역흡착측정 법, 미세중화법 등을 이용할 수 있다[2]. 최근에는 바이러스의 $\mathrm{S}$ 분절의 뉴클레오캡시드 단백 부위를 재조합한 뒤 항원으로 이용하는 방법으로 이중항원샌드위치법이 개발되었는데, 이 검사법은 사람의 항체뿐만이 아니라 동물의 항체도 검출할 수 있다[31]. 


\section{감별진단}

SFTS의 임상 소견은 아나플라즈마증, 신증후군출혈열, 렙 토스피라증 등과 비슷하여 이들 질환과 감별이 필요하다[2]. 아나플라즈마증은 참진드기(Ixodes tick)에 의해 매개되는 인 수공통감염병이며 SFTS와 유사하게 백혈구 감소증과 혈소 판 감소증이 동반되지만 소화기 증상은 흔하지 않다[32]. 이 질환은 최근 중국과 일본에서도 보고되었다[33,34]. 우리나라 에서도 아나플라즈마가 야생동물에서 검출되었고[14,35,36] 진드기에 물린 뒤 발생한 아나플라즈마증 환자도 보고된 바 있다[37]. 특히 아나플라즈마증은 독시사이클린으로 치료가 가능하므로 SFTS로 판단하고 초기에 항생제 투여를 하지 않 으면 항생제로 치료할 수 있는 질환을 놓칠 수 있다[32].

신증후군출혈열은 초기 발열기에 소화기 증상과 복통이 있다는 점에서 SFTS와 유사하다. 그러나 얼굴, 목, 흥부의 홍조, 결막충혈, 안와주위부종, 출혈 및 파종혈관내응고 등 은 SFTS의 초기에는 흔하지 않은 소견이다[38]. 렙토스피라 증도 발병 초기에 발열, 두통, 근육통, 복통 등이 발생한다는 점에서 SFTS와 유사하다. 그러나 발진이나 황달과 같은 렙 토스피라증의 주증상이 SFTS에서는 흔하지 않다[39].

\section{치료 및 예방}

SFTSV에 대한 항바이러스제는 아직 개발되지 않았다[27]. 중국에서는 2012년부터 리바비린 정주를 치료지침에 도입하 고 있으나 최근 발표된 치료 결과에서는 리바비린 투여군과 비투여군 간 사망률에 차이는 없었다[27]. 따라서 SFTS 치료 는 수혈, 신대체요법 등 장기부전에 대한 보존요법이 근간을 이룬다.

백신은 아직 개발되지 않았으며 예방을 위해서 야외 활동 시 진드기에 물리지 않도록 주의하는 것이 필요하다[16].

\section{결 론}

SFTS는 중국, 일본 그리고 우리나라에 새로이 출현한 진 드기 매개 감염병이다. 주요한 임상 소견은 발열, 백혈구 감 소증, 혈소판 감소증, 소화기 증세이며 다장기부전증으로 사 망할 수 있다. 아직 효과적인 항바이러스제나 백신은 없다. 국내에서 발생하는 아나플라스마증, 신증후군출혈열과의 감 별이 중요하다.
중심 단어: 중증열성혈소판감소증후군; 플레보바이러스; 버냐바이러스

\section{REFERENCES}

1. Jones KE, Patel NG, Levy MA, et al. Global trends in emerging infectious diseases. Nature 2008;451:990-993.

2. Yu XJ, Liang MF, Zhang SY, et al. Fever with thrombocytopenia associated with a novel bunyavirus in China. N Engl J Med 2011;364:1523-1532.

3. Ding F, Zhang W, Wang L, et al. Epidemiologic features of severe fever with thrombocytopenia syndrome in China, 2011-2012. Clin Infect Dis 2013;56:1682-1683.

4. Zhang YZ, He YW, Dai YA, et al. Hemorrhagic fever caused by a novel Bunyavirus in China: pathogenesis and correlates of fatal outcome. Clin Infect Dis 2012;54:527-533.

5. Gai ZT, Zhang Y, Liang MF, et al. Clinical progress and risk factors for death in severe fever with thrombocytopenia syndrome patients. J Infect Dis 2012;206:1095-1102.

6. Takahashi T, Maeda K, Suzuki T, et al. The first identification and retrospective study of severe fever with thrombocytopenia syndrome in Japan. J Infect Dis 2013 Dec 12 [Epub]. http://dx.doi.org/10.1093/infdis/jit603.

7. Kim KH, Yi J, Kim G, et al. Severe fever with thrombocytopenia syndrome, South Korea, 2012. Emerg Infect Dis 2013; 19:1892-1894.

8. Elliott RM. Emerging viruses: the Bunyaviridae. Mol Med 1997;3:572-577.

9. Liu Y, Li Q, Hu W, et al. Person-to-person transmission of severe fever with thrombocytopenia syndrome virus. Vector Borne Zoonotic Dis 2012;12:156-160.

10. Korea Centers for Disease Control and Prevention. A current state of confirmed cases of severe fever with thrombocytopenia syndrome in Korea (Nov 28, 2013) [Internet]. Osong: Korea Centers for Disease Control and Prevention, c2013 [cited 2014 Feb 17]. Available from: http://cdc.go.kr/CDC/ intro/CdcKrIntro0201.jsp?menuIds=HOME001-MNU1154 -MNU0005-MNU0011\&cid=21944.

11. Zhang YZ, Zhou DJ, Qin XC, et al. The ecology, genetic diversity, and phylogeny of Huaiyangshan virus in China. J Virol 2012;86:2864-2868.

12. Zhao L, Zhai S, Wen H, et al. Severe fever with thrombocytopenia syndrome virus, Shandong Province, China. Emerg Infect Dis 2012;18:963-965.

13. Niu G, Li J, Liang M, et al. Severe fever with thrombocytopenia syndrome virus among domesticated animals, China. Emerg Infect Dis 2013;19:756-763.

14. Chae JS, Yu do H, Shringi S, et al. Microbial pathogens in ticks, rodents and a shrew in northern Gyeonggi-do near the 
DMZ, Korea. J Vet Sci 2008;9:285-293.

15. Kim CM, Yi YH, Yu DH, et al. Tick-borne rickettsial pathogens in ticks and small mammals in Korea. Appl Environ Microbiol 2006;72:5766-5776.

16. Korea Centers for Disease Control and Prevention. Prevention of severe fever with thrombocytopenia syndrome in Korean [Internet]. Osong: Korea Centers for Disease Control and Prevention, c2013 [cited 2014 Feb 17]. Available from: http://cdc.go.kr/CDC/intro/CdcKrIntro0201.jsp?menuIds= HOME001-MNU1154-MNU0005-MNU0011\&cid=20790.

17. Tang $\mathrm{X}, \mathrm{Wu} \mathrm{W}$, Wang $\mathrm{H}$, et al. Human-to-human transmission of severe fever with thrombocytopenia syndrome bunyavirus through contact with infectious blood. J Infect Dis 2013;207:736-739.

18. Chen H, Hu K, Zou J, Xiao J. A cluster of cases of humanto-human transmission caused by severe fever with thrombocytopenia syndrome bunyavirus. Int J Infect Dis 2013; 17:e206-208

19. Gai Z, Liang M, Zhang Y, et al. Person-to-person transmission of severe fever with thrombocytopenia syndrome bunyavirus through blood contact. Clin Infect Dis 2012;54: 249-252.

20. Bao CJ, Guo XL, Qi X, et al. A family cluster of infections by a newly recognized bunyavirus in eastern China, 2007: further evidence of person-to-person transmission. Clin Infect Dis 2011;53:1208-1214.

21. Deng B, Zhang S, Geng Y, et al. Cytokine and chemokine levels in patients with severe fever with thrombocytopenia syndrome virus. PLoS One 2012;7:e41365.

22. Sun Y, Jin C, Zhan F, et al. Host cytokine storm is associated with disease severity of severe fever with thrombocytopenia syndrome. J Infect Dis 2012;206:1085-1094.

23. Jin $\mathrm{C}$, Liang $\mathrm{M}$, Ning $\mathrm{J}$, et al. Pathogenesis of emerging severe fever with thrombocytopenia syndrome virus in C57/BL6 mouse model. Proc Natl Acad Sci USA 2012;109: 10053-10058.

24. Shin J. Epidemiologic characteristics of Korean patients with severe fever with thrombocytopenia syndrome. Proceeding of 2013 the Communicable Disease Control Conference; 2013 Nov 21-22; Yeosu: Korea Center for Disease Control and Prevention, 2013:11-16.

25. Xu B, Liu L, Huang X, et al. Metagenomic analysis of fever, thrombocytopenia and leukopenia syndrome (FTLS) in Henan Province, China: discovery of a new bunyavirus. PLoS Pathog 2011;7:e1002369.

26. Zhang YZ, Zhou DJ, Xiong Y, et al. Hemorrhagic fever caused by a novel tick-borne Bunyavirus in Huaiyangshan, China. Zhonghua Liu Xing Bing Xue Za Zhi 2011;32:209-220.

27. Liu W, Lu QB, Cui N, et al. Case-fatality ratio and effectiveness of ribavirin therapy among hospitalized patients in china who had severe fever with thrombocytopenia syndrome. Clin Infect Dis 2013;57:1292-1299.

28. Quantai X, Fengzhe C, Xiuguang S, Dongge C. A study of cytological changes in the bone marrow of patients with severe Fever with thrombocytopenia syndrome. PLoS One 2013;8:e83020.

29. Korea Centers for Disease Control and Prevention. Case Definition for National Notifiable Infectious Diseases in Korean [Internet]. Osong: Korea Centers for Disease Control and Prevention, c2014 [cited 2014 Feb 18]. Availabel from: http://www.cdc.go.kr/CDC/together/CdcKr Together0302.jsp?menuIds=HOME001-MNU1154-MNU0 004-MNU0088\&fid $=51 \&$ q_type $=\&$ q_value $=\&$ cid $=22130$ \&pageNum $=$.

30. Sun L, Hu Y, Niyonsaba A, et al. Detection and evaluation of immunofunction of patients with severe fever with thrombocytopenia syndrome. Clin Exp Med 2013 Sep 26 [Epub]. http://dx.doi.org/10.1007/s10238-013-0259-0.

31. Jiao Y, Zeng X, Guo X, et al. Preparation and evaluation of recombinant severe fever with thrombocytopenia syndrome virus nucleocapsid protein for detection of total antibodies in human and animal sera by double-antigen sandwich enzyme-linked immunosorbent assay. J Clin Microbiol 2012; 50:372-377.

32. Dumler JS, Choi KS, Garcia-Garcia JC, et al. Human granulocytic anaplasmosis and Anaplasma phagocytophilum. Emerg Infect Dis 2005;11:1828-1834.

33. Zhang L, Liu Y, Ni D, et al. Nosocomial transmission of human granulocytic anaplasmosis in China. JAMA 2008; 300:2263-2270.

34. Ohashi N, Gaowa, Wuritu, et al. Human granulocytic Anaplasmosis, Japan. Emerg Infect Dis 2013;19:289-292.

35. Chae JS, Kim CM, Kim EH, et al. Molecular epidemiological study for tick-borne disease (Ehrlichia and Anaplasma spp.) surveillance at selected U.S. military training sites/ installations in Korea. Ann N Y Acad Sci 2003;990:118-125.

36. Kang JG, Ko S, Kim YJ, et al. New genetic variants of Anaplasma phagocytophilum and Anaplasma bovis from Korean water deer (Hydropotes inermis argyropus). Vector Borne Zoonotic Dis 2011;11:929-938.

37. ProMedmail. Anaplasmosis-South Korea: (KW) 1st clinical case description [Internet]. Boston: ProMedmail, c2013 [cited 2014 Feb 18]. Available from: http://www.promedmail. org.

38. Peters CJ, Simpson GL, Levy H. Spectrum of hantavirus infection: hemorrhagic fever with renal syndrome and hantavirus pulmonary syndrome. Annu Rev Med 1999;50: 531-545.

39. Levett PN. Leptospirosis. Clin Microbiol Rev 2001;14: 296-326. 